\title{
The In Vitro Growth and Serial Passage of RA 27/3 Rubella Vaccine Virus in Cord Blood Mononuclear Leukocytes from Normal Babies
}

\author{
KARIN NIELSEN, ALICE GARAKIAN, LISA M. FRENKEL, AND JAMES D. CHERRY \\ Division of Infectious Diseases, Department of Pediatrics, UCLA Medical Center, UCLA School of \\ Medicine, Los Angeles, California 90024 [K.N., A.G., J.D.C.], and Division of Infectious Diseases, \\ Department of Pediatrics, University of Washington, School of Medicine, Children's Hospital, \\ Seattle, Washington 98105-0833 [L.M.F.]
}

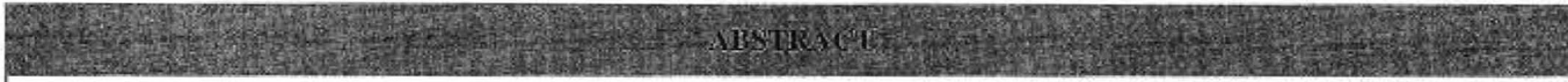

Because of our inability to isolate rubella virus from peripheral blood lymphocytes from patients with chronic symptoms after rubella immunization we performed a series of experiments with cord blood mononuclear cells (CBL) to determine whether and to what extent these cells supported the growth of rubella virus in vitro. CBL were stimulated with phytohemagglutinin for 48-72 h, washed, and inoculated with 1000 tissue culture 50\% infection dose of rubella virus and placed in RPMI 1640 medium with $10 \%$ fetal bovine serum and IL-2. Approximately every $9 \mathrm{~d}$ the volume was halved, and new CBL were added. Aliquots at 2 to 9-d intervals were obtained and quantitatively cultured in

African green monkey tissue culture. Rubella virus growth was determined by echovirus 11 challenge. Controls consisted of rubella virus in RPMI 1640 medium. Rubella virus persisted in CBL culture longer than in control medium in seven of 11 experiments, and in three instances there was evidence of productive infection. (Pediatr Res 37: 623-625, 1995)
Abbreviations
CBL, cord blood lymphocyte
TCID $_{50}, 50 \%$ tissue culture infective dose

Arthralgias are common in postpubertal women after immunization with rubella vaccine (1). Infrequently chronic or recurrent arthralgias, sometimes with arthritis and/or varied neurologic manifestations have been noted in vaccinees (2). Several studies have suggested that these chronic illnesses are the result of persistent rubella vaccine virus infection involving mononuclear leukocytes (3-5). Because of these reports our group studied a number of adults with chronic symptoms after rubella immunization, and we were unable to isolate rubella virus from their peripheral blood lymphocytes (6).

Because of our inability to duplicate the findings of others, we have attempted to infect CBL in vitro with RA 27/3 vaccine virus. The purpose of the presently reported studies was to determine under controlled conditions whether rubella vaccine virus would persist and grow in immunologically naive mononuclear cells.

\section{METHODS}

Preparation of $\boldsymbol{C B L}$. Umbilical cord blood specimens from normal term newborns, at the UCLA Medical Center, were obtained in $10-\mathrm{mL}$ tubes containing heparin. $\mathrm{CBL}$ were obtained by

Received March 31, 1994; accepted January 6, 1995.

Correspondence: Karin Nielsen, M.D., UCLA School of Medicine, Department of Pediatrics. MDCC Rm 22-442, 10833 LeConte Ave., Los Angeles CA 90024.

Supported by a grant from Merck, Sharp \& Dohme. centrifugation with Lymphoprep (Nycomed Pharmaceuticals, Oslo, Norway) and resuspended in RPMI 1640 medium (Irvine Scientific, Santa Ana, CA) with phytohemagglutinin (Difco, Detroit, MI) for $48-72 \mathrm{~h}$ at $36^{\circ} \mathrm{C}$. After incubation, cells were washed twice in phosphate-buffered saline and resuspended in $2 \mathrm{~mL}$ of RPMI medium. Viable cells were counted using trypan blue exclusion, and two pellets were prepared with $5 \times$ $10^{6}$ cells in each.

Experimental design. An outine of the experimental design is presented in Figure 1. The rubella vaccine virus was Meruvax II (Merck, Sharp \& Dohme, West Point, PA). Penicillin/ streptomycin/Fungizone and fetal bovine serum were purchased from Irvine Scientific, Santa Ana, CA, and IL-2 was obtained from Boehringer Mannheim, Indianapolis, IN.

Viral cultures. Cultures were performed in African green monkey tissue culture cells obtained from Bio Whittaker, Walkersville, M.D.. Aliquots $(0.5 \mathrm{~mL})$ for culture were diluted from $10^{0}$ to $10^{-3}$ and $0.5 \mathrm{~mL}$ of each dilution were inoculated into single African green monkey kidney tissue culture tubes. In some experiments dilutions were extended to $10^{-4}$ and duplicate African green monkey kidney tissue culture tubes were used.

Cultures were incubated for $7 \mathrm{~d}$ at $36^{\circ} \mathrm{C}$ and the presence of rubella virus determined by challenge with a 100 TCID $_{50}$ 


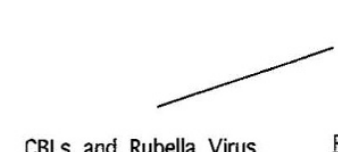

(1)

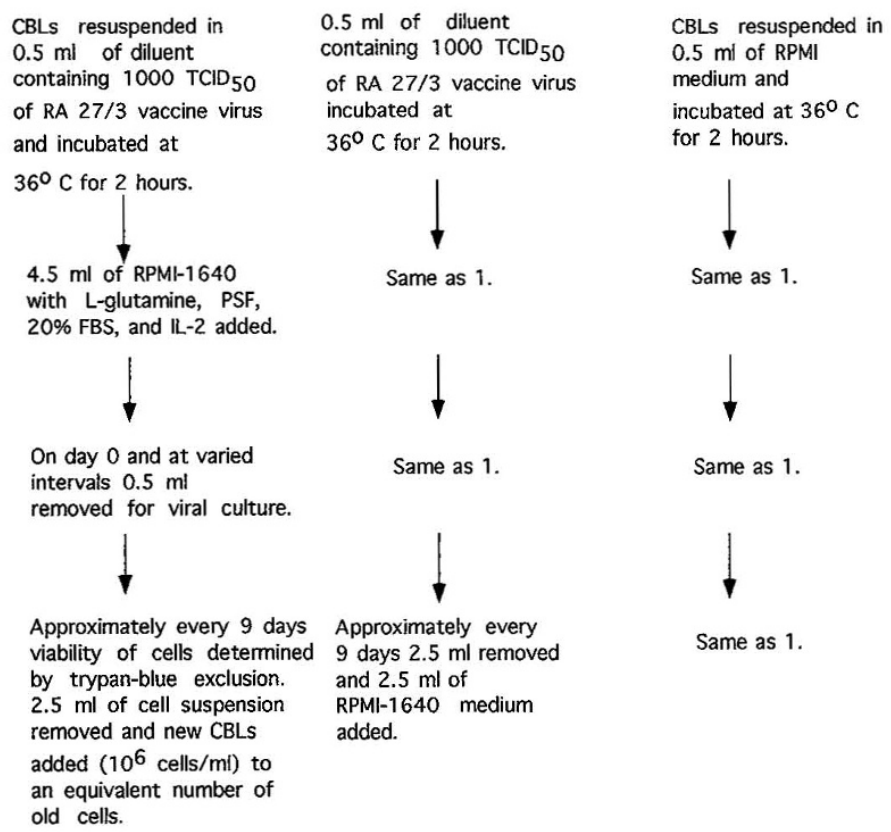

Figure 1. Experimental design. Chronology of events in individual experiments.

infective dose of echovirus 11 (7). All cultures were blind passed once and after $7 \mathrm{~d}$ of incubation were rechallenged with echovirus 11. Presence of rubella virus infection was assumed if typical enteroviral cytopathic effect did not occur.

When rubella virus was recovered from $\mathrm{CBL}$ for a longer duration of time than from the controls, we considered this evidence of virus persistence. Virus growth and productive infection was considered to have occurred if the titer of virus from the CBL was found to be greater than that of the original inoculum and if it did not decrease over time due to specimen dilution associated with the addition of new CBL every $9 \mathrm{~d}$.

\section{RESULTS}

Eleven experiments were performed, and the results are summarized in Table 1. Rubella virus persisted in CBL longer than in controls in 7 of 11 experiments (experiments 4-10) and in three instances there was evidence of productive infection (experiments 6-8). In two experiments ( 1 and 11 ) infection did not occur and in two others (experiments 2 and 3 ) the studies were terminated without the addition of new CBL.

The longitudinal events in experiment 6 are presented in Figure 2. In this experiment the virus titer increased 100 -fold and productive infection persisted for $145 \mathrm{~d}$. Similar findings were noted in experiments 7 and 8 .

\section{DISCUSSION}

After the report of the isolation of rubella virus in 1962 (7) it was found that infants with congenital rubella had prolonged infections (7-14); viremia occurred and leukocytes were found to be infected. In contrast, persistent infection was not noted in postnatal illnesses due to rubella virus. In 1965 Mellman et al. (15) noted that leukocytes from a seronegative woman had only a limited ability to support the replication of rubella virus when compared with other viruses such as measles, echovirus 9, and herpes simplex (15).

In recent years there has been a renewed interest in the possibility of persistent rubella virus infection (2) due to a series of publications relating arthritic and other chronic symptoms in previously vaccinated adults with persistent rubella virus in peripheral blood lymphocytes of the affected patients (3-5). These studies led us to search for persistent rubella virus infections in peripheral blood lymphocytes from subjects with

Table 1. The growth and persistence of RA 27/3 rubella vaccine virus in CBL: summary of 11 experiments

\begin{tabular}{|c|c|c|c|c|c|c|c|c|}
\hline $\begin{array}{l}\text { Exp. } \\
\text { no. }\end{array}$ & $\begin{array}{c}\text { Days virus } \\
\text { culture attempted }\end{array}$ & $\begin{array}{l}\text { Maximum titer* } \\
\text { of rubella virus } \\
\text { in CBL }\end{array}$ & $\begin{array}{l}\text { Last day } \\
\text { rubella virus } \\
\text { isolated from } \\
\text { CBL }\end{array}$ & $\begin{array}{l}\text { Titer* on last } \\
\text { day rubella } \\
\text { virus isolated } \\
\text { from CBL }\end{array}$ & $\begin{array}{l}\text { Last day } \\
\text { rubella virus } \\
\text { isolated from } \\
\text { controls }\end{array}$ & $\begin{array}{l}\text { Titer* of rubella } \\
\text { virus in controls } \\
\text { on last day of } \\
\text { isolation }\end{array}$ & $\begin{array}{l}\text { Evidence of } \\
\text { persistence of } \\
\text { rubella virus } \\
\text { in CBL }\end{array}$ & $\begin{array}{l}\text { Evidence of } \\
\text { growth of } \\
\text { rubella virus } \\
\text { in CBL }\end{array}$ \\
\hline 1 & $2,4,7$ & 320 & 4 & 3.2 & 7 & 3.2 & No & No \\
\hline 2 & $0,3,5$ & 320 & 5 & 3.2 & 5 & 3.2 & No & No \\
\hline 3 & $2,4,5,6$ & 32 & 6 & 3.2 & 6 & 3.2 & No & No \\
\hline 4 & $0,5,7,9,11,13$ & 320 & 13 & 320 & 5 & 3.2 & Yes & No \\
\hline 5 & $0,5,12$ & 320 & 5 & 3.2 & 0 & 3200 & Yes & No \\
\hline 6 & $\begin{array}{c}1,7,14,19,26,31 \\
40,47,55,66 \\
75,83,89,103 \\
117,130,145\end{array}$ & 32000 & 145 & 3200 & 0 & 320 & Yes & Yes \\
\hline 7 & $\begin{array}{l}0,7,12,20,27,33 \\
\quad 42,50,63,70 \\
78,84\end{array}$ & 3200 & 84 & 3200 & 0 & 320 & Yes & Yes \\
\hline 8 & $\begin{array}{l}0,7,12,20,27,33 \\
42,50,63,70 \\
78,84\end{array}$ & 3200 & 84 & 3200 & 0 & 320 & Yes & Yes \\
\hline 9 & $0,7,13,18$ & 320 & 13 & 3.2 & 0 & 320 & Yes & No \\
\hline 10 & $0,5,13$ & 3200 & 5 & 32 & 0 & 320 & Yes & No \\
\hline 11 & $0,5,13$ & 320 & 0 & 320 & 0 & 320 & No & No \\
\hline
\end{tabular}

$* \mathrm{TCID}_{50}$. 


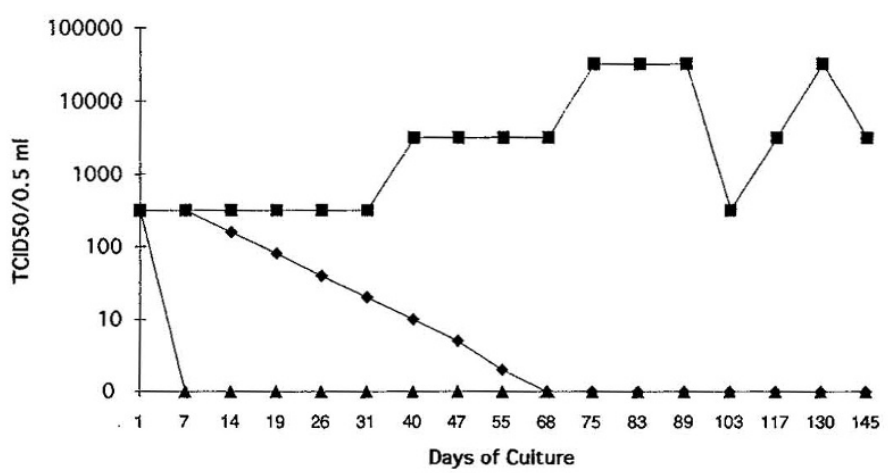

Figure 2. The longitudinal events in experiment $6 . \mathbf{q}=$ virus titer in $\mathrm{CBL}$ culture; $\boldsymbol{\Delta}=$ virus titer in control medium; $\boldsymbol{\nabla}=$ calculated decrease in viral titer by dilution associated with removal of old and addition of new CBL.

chronic illnesses following immunization (6). Although we were able to isolate virus from two vaccinees shortly after immunization and from one patient with natural infection, we were unable to isolate virus from any patients with chronic illnesses. In addition, since we also isolated rubella virus from the pharynx and from polymorphonuclear leukocytes of recent vaccinees we questioned the tropism of rubella virus for lymphocytes and therefore initiated the present study.

As noted in Table 1 and Figure 2, productive rubella virus infection was demonstrated in three of 11 experiments.

Since rubella virus can infect and replicate in CBL in vitro, it is possible that persistent rubella virus infection of peripheral blood lymphocytes can occur. Therefore in spite of our previ- ous negative studies in patients with chronic illnesses it seems reasonable to prospectively study adult vaccinees who develop arthralgias and other symptoms for persistent rubella virus infections.

\section{REFERENCES}

1. Advisory Committee of Immunization Practices (ACIP) 1990 Rubella prevention. Recommendations of the Immunization Practices Advisory Committee. Morb Mortal Wkly Rep 39:1-18

2. Howson C, Katz M, Johnston R, Fineberg H 1992 Chronic arthritis after rubella vaccination. Clin Infect Dis 15:307-312

3. Tingle A, Chantler J, Pot K, Paty D, Ford D 1985 Postpartum rubella immunization: association with development of prolonged arthritis, neurological sequelae, and chronic rubella viremia. J Infect Dis 152:606-612

4. Chantler J, Ford D, Tingle A 1981 Rubella-associated arthritis: rescue of rubella virus from peripheral blood lymphocytes two years postvaccination. Infect Immun 32:1274-1280

5. Chantler J, Ford D, Tingle A 1982 Persistent rubella infection and rubella-associated arthritis. Lancet 8285:1323-1325

6. Frenkel L, Garakian A, Cherry J 1991 Rubella virus (RV): no evidence of persistent infection following immunization with RA 27/3 or wild type infection. ICAAC Prog Abstr 31:1294 (abstr)

7. Parkman P, Buescher E, Artenstein M 1962 Recovery of rubella virus from army recruits. Proc Soc Exp Biol Med 3:225-230

8. Rawls W 1974 Viral persistence in congenital rubella. Prog Med Virol 18:273-288

9. Simons M, Jack I 1968 Lymphocyte viraemia in congenital rubella. Lancet 7575:953954

10. Phillips C, Melnick J, Yow M, Bayatpour M, Burkhardt M 1965 Persistence of virus in infants with congenital rubella and in normal infants with a history of maternal rubella. J Am Med Assoc 193:1027-1029

11. Jack I, Grutzner J 1969 Cellular viraemia in babies infected with rubella virus before birth. Br Med J 1:289-292

12. Shewmon D, Cherry J, Kirby S 1982 Shedding of rubella virus in a $4 \frac{1}{2} 2$-year-old boy with congenital rubella. Pediatr Infect Dis 1:342-343

13. Menser M, Forrest J, Slinn R, Nowak M, Dorman D 1971 Rubella viruria in a 29-year-old woman with congenital rubella. Lancet 7728:797-798

14. Michaels R 1969 Immunologic aspects of congenital rubella. Pediatrics 43:339-350

15. Mellman W, Plotkin S, Moorhead P, Hartnett E 1965 Rubella infection of human leukocytes. Am J Dis Child 110:473-476 